\title{
PENINGKATAN PEMBERDAYAAN KELOMPOK WANITA TANI DUSUN WONOREJO KOTA BATU MELALUI PELATIHAN PEMBUATAN PRODUK SUSU PROBIOTIK-SARI BUAH SEBAGAI MINUMAN KESEHATAN
}

\section{(EMPOWERING "WANITA TANI" GROUP OF WONOREJO BATU THROUGH TRAINING OF THE PRODUCTION OF PROBIOTIC DAIRY- FRUITY PRODUCTS AS A HEALTH DRINK)}

\author{
Nuzul Wahyuning Diyah ${ }^{1}$ Isnaeni $^{2}$, Asri Darmawati ${ }^{3}$, Suko Hardjono $^{4}$ \\ ${ }^{1,2,3,4}$ Fakultas Farmasi Universitas Airlangga \\ e-mail: nuzul-w-d@ff.unair.ac.id
}

\begin{abstract}
Wonorejo village in Batu city is known as a vegetable and fruit producing area. Another popular product of Batu mostly is fresh dairy milk and only a small amount of processed products while the cow milk collected in KUD Batu has reached 16-17 tons per day. The problem was that the target community had no experiences in processing cow milk using probiotic microbes. The purpose was transfering of science and technology about the production of probiotic milk combined with fruit juice. This program was specifically directed to increase the empowerment of Kelompok Wanita Tani "Wonoasri" in Wonorejo, in developing of fruity- probiotic dairy products to increase the diversification of products with higher economic value. The method included workshop and technical assistance, which were carried out in a serie of steps: 1) exploring the knowledge of target by surveys and pre test, 2) lecturing and discussion, 3) demonstrating how to prepare and characterize the probiotic milk products, 4) training the preparation of product, 5) product characterization and packaging assistance, 6) evaluation. The results of this program were the target community gained increase in knowledge and experience, and they could produce fruity probiotic milk. In addition, we expected that they would increase their understanding and enthusiasm to appreciate the potency of their territory in order to improve the nation's competitiveness.
\end{abstract}

Keywords : fruity-probiotic milk, workshop, kelompok wanita tani, wonorejo

abstrak

Desa Wonorejo di kota Batu dikenal sebagai daerah penghasil sayur dan buah. Produk populer lain dari Batu adalah susu segar dan sejumlah kecil produk olahan. Susu sapi dikumpulkan di KUD Batu. Masalahnya adalah bahwa komunitas target tidak memiliki pengalaman dalam memproses susu sapi menggunakan mikroba probiotik. Tujuannya adalah mentransfer ilmu pengetahuan dan teknologi tentang produksi susu probiotik yang dikombinasikan dengan jus buah. Program ini diarahkan untuk pemberdayaan Kelompok Tani Wanita "Wonoasri" di Wonorejo, dalam mengembangkan produk susu buah-probiotik untuk diversifikasi produk dengan nilai ekonomi lebih tinggi. Metode tersebut termasuk lokakarya dan bantuan teknis, dalam serangkaian langkah: 1) mengeksplorasi pengetahuan target dengan survei dan pra-tes, 2) ceramah dan diskusi, 3) menunjukkan bagaimana mempersiapkan dan mengkarakterisasi produk susu probiotik, 4) pelatihan persiapan produk, 5) karakterisasi produk dan bantuan pengemasan, 6) evaluasi. Hasil program ini adalah komunitas sasaran memperoleh peningkatan dalam pengetahuan dan pengalaman, dan mereka dapat menghasilkan susu probiotik buah. Selain itu, kami berharap bahwa mereka akan meningkatkan pemahaman dan antusiasme mereka untuk menghargai potensi wilayah mereka untuk meningkatkan daya saing bangsa.

Kata kunci: susu buah-probiotik, pengolahan, kelompok wanita tani, wonorejo 


\section{PENDAHULUAN}

Salah satu implementasi dari misi Perguruan Tinggi yang berperan sebagai agent of economic development adalah menghasilkan inovasi yang dapat memberikan manfaat ekonomis bagi masyarakat luas. Faktor yang tidak kalah pentingnya adalah bagaimana ilmu pengetahuan dan teknologi yang dikembangkan melalui sistem Perguruan Tinggi dapat menyentuh kebutuhan masyarakat sesuai kapasitas lokal di wilayah masyarakat tersebut.

Kota Batu terkenal dan menarik bagi para wisatawan nasional maupun internasional karena panorama yang indah dan hawa yang sejuk. Wonorejo merupakan salah satu dusun di kecamatan Bumiaji Kota Batu, yang terletak pada ketinggian $1.300 \mathrm{~s} / \mathrm{d} 1700 \mathrm{~m}$ dari permukaan laut. Banyaknya curah hujan rerata $8,9 \mathrm{~mm}$ serta suhu rerata $18 \mathrm{~s} / \mathrm{d} 24$ ${ }^{\circ} \mathrm{C}$, menjadikan dusun Wonorejo daerah subur sehingga dikenal karena hasil bumi berupa buah-buahan dan sayuran. Mata pencaharian penduduk sehari-hari adalah sebagai petani sayur-mayur dan apel; sebagian besar penduduk bekerja sebagai buruh tani (Akaibara, 2016).

Di sisi lain, secara keseluruhan produk kota Batu yang terkenal adalah susu sapi perah dan produk olahan susu sapi perah, seperti : susu pasteurisasi dan susu fermentasi (yogurt). Saat ini jumlah sapi di kota Batu sudah mencapai lebih dari 4300 ekor dan setoran susu ke KUD Batu berada di kisaran 16 ton hingga 17 ton per hari (UPTPT HMT Batu, 2015). Di dekat dusun Wonorejo, tepatnya di Coban Talun, terdapat lahan industri peternak sapi. Selain pangsa pasar dalam negeri, produksi susu dari seluruh wilayah Batu juga untuk diekspor (Muiz, 2015).

Masyarakat sasaran tergabung dalam kelompok tani yang telah melakukan berbagai aktivitas pemberdayaan lahan di wilayah desa, yaitu: menanam sayar-mayur di sepanjang tepi jalan perumahan, menanam jamur tiram, dan sebagainya, untuk menambah pendapatan keluarga dan kelompok. Oleh karena itu program yang dilaksanakan terhadap masyarakat sasaran di dusun Wonorejo lebih bersifat peningkatan pemberdayaan yang sudah berjalan. Dari hasil pemetaan kapasitas dan potensi alam serta perkembangan usaha masyarakat Batu, program ini diarahkan untuk meningkatkan pemberdayaan Kelompok Wanita Tani "Wonoasri" di dusun Wonorejo, Kecamatan Bumiaji, khususnya terkait pengembangan produk olahan susu sapi perah guna meningkatkan diversifikasi produk olahan susu yang memiliki nilai jual lebih tinggi.

Produk olahan susu sapi perah antara lain: susu pasteurisasi, yogurt, permen, es krim, dan es lilin. Yogurt adalah salah satu komoditi pangan yang populer dikonsumsi di daerah berhawa dingin dan sangat disukai oleh wisatawan mancanegara. Yogurt dihasilkan melalui proses fermentasi susu sapi perah yang ditambah bibit berupa mikroba probiotik sehingga sering disebut susu probiotik. Mikroba probiotik memiliki aktivitas menghasilkan metabolit yang mempunyai berbagai khasiat, antara lain: mempertahankan dan meningkatkan daya tahan tubuh; antibakteri sehingga bermanfaat sebagai antiinfeksi, misalnya pada kondisi diare; anti alergi; menurunkan kolesterol. Kombinasi susu probiotik dengan berbagai sari buah, akan menghasilkan susu probiotik-sari buah yang kaya vitamin, mineral, serta beberapa enzim yang sangat bermanfaat bagi kesehatan tubuh (Isnaeni dkk, 2015). 
Fabrikasi untuk menghasilkan susu probiotik dapat dilakukan dengan teknologi yang sederhana, dalam waktu cepat dan tidak memerlukan peralatan canggih, dapat diproduksi skala industri maupun untuk konsumsi rumah tangga. Permasalahannya, khalayak sasaran belum berpengalaman memproduksi susu probiotik-sari buah. Untuk meningkatkan pengetahuan, pengalaman dan ketrampilan khalayak sasaran, dilakukan pemberian informasi/penyuluhan, pelatihan, serta pendampingan dalam pembuatan produk susu probiotik yang memenuhi syarat kesehatan (higienis).

Tujuan kegiatan ini adalah transfer IPTEK dari Fakultas Farmasi kepada khalayak sasaran, yang diharapkan mampu menghasilkan produk susu probiotik-sari buah untuk meningkatkan nilai ekonomi produk olahan susu dan mengembangkannya secara mandiri dalam kelompok UKM. Lebih lanjut, masyarakat target diharapkan meningkat pemahaman dan semangatnya untuk menghargai potensi daerahnya guna meningkatkan daya saing bangsa.

\section{METODE PENGABDIAN MASYARAKAT Bentuk dan pelaksanaan Kegiatan}

Bentuk kegiatan pengabdian masyarakat ini adalah pelatihan dan pendampingan, yang dilaksanakan pada khalayak sasaran Kelompok Wanita Tani "Wonoasri" di Dusun Wonorejo. Tahap-tahap pelaksanaan kegiatan adalah sebagai berikut: (1) Penentuan lokasi, meliputi survei lokasi dan koordinasi dengan kelompok masyarakat, (2) visitasi ke Dusun Wonorejo untuk merancang tata letak di lokasi pelatihan, pemberian kuesioner/pre test, dan penentuan jadwal pelatihan, (3) penyiapan bahan pelatihan, meliputi: preparasi starter probiotik, standarisasi prosedur, dan pembuatan buku panduan, (4) penyiapan peralatan dan perlengkapan pelatihan, termasuk alat peraga dan post test, (5) pelaksanaan pelatihan meliputi: penyuluhan, peragaan, dan praktek pembuatan produk (6) pendampingan untuk karakterisasi produk dan pengemasan sehari setelah pelatihan, (7) evaluasi kegiatan pelatihan, dan pendampingan pasca pelatihan.

Tahap penentuan lokasi hingga penyiapan bahan pelatihan dilakukan oleh Tim Penulis, pelaksanaan pelatihan dilakukan bersama Tim Dosen Fakultas Farmasi Universitas Airlangga yang seluruhnya beranggotakan 14 orang, dibantu 8 mahasiswa yang terlatih. Keterlibatan mahasiswa tidak hanya sekedar membantu tetapi juga meningkatkan ketrampilan dan penerapan ilmu, serta dapat membuka kesadaran akan pentingnya membagikan pengetahuan untuk kepentingan masyarakat luas sebagai wujud pengamalan ilmu pengetahuan.

\section{Materi Pelatihan dan Pendampingan}

Peserta dibekali prosedur pembuatan susu probiotik-sari buah dalam bentuk buku panduan, kemudian diberi penyuluhan dan bimbingan praktek tentang: cara sterilisasi susu; pemilihan buah dan preparasi sari buah; formula/takaran starter probiotik, susu, dan sari buah; cara pembuatan sediaan susu probiotik-sari buah; cara pengemasan produk; karakterisasi produk susu probiotik-sari buah secara sederhana. Setelah penyuluhan dan praktek pembuatan susu probiotik-sari buah, peserta diberi post test untuk mengetahui tingkat pengetahuan tentang susu probiotik setelah memperoleh pelatihan. 
Pendampingan pasca pelatihan dimulai 24 jam setelah pelatihan, meliputi karakterisasi produk susu probiotik-sari buah yang dihasilkan peserta selama pelatihan, dan pengemasan produk. Pendampingan masih berlanjut di luar kegiatan pelatihan, melalui konsultasi yang terkait dengan pembuatan secara mandiri produk susu probiotik-sari buah yang berkualitas, cara mengatasi permasalahan selama pengolahan susu, proses perizinan dan pemasaran.

\section{Evaluasi pelaksanaan kegiatan}

Keberhasilan program dievaluasi dari peningkatan aspek kognitif, afektif, dan psikomotor khalayak sasaran, yaitu: (1) berdasarkan kemampuan khalayak sasaran membuat produk susu probiotik-sari buah dan menganalisis karakter produk yang dihasilkan selama pelatihan. (2) berdasarkan hasil post test secara tertulis.

\section{HASIL DAN PEMBAHASAN}

Kegiatan pengabdian kepada masyarakat ini dapat dilaksanakan dengan baik. Khalayak sasaran, warga masyarakat sekitar, dan perangkat desa sangat mendukung kegiatan ini berdasarkan fasilitasi dan bantuan yang diberikan sepanjang proses, mulai tahap survei sampai akhir pelatihan, yang berlanjut dengan pendampingan. Berdasarkan respons terhadap kegiatan pelatihan dan pendampingan, terdapat antusiasme yang tinggi dari khalayak sasaran dalam mengikuti kegiatan tersebut.

Tahap persiapan yang meliputi penentuan lokasi, visitasi ke dusun Wonorejo, penyiapan bahan dan prosedur serta pembuatan buku panduan, penyiapan peralatan dan perlengkapan, membutuhkan waktu paling panjang. Kegiatan pada tahap ini didokumentasikan pada Gambar 1.

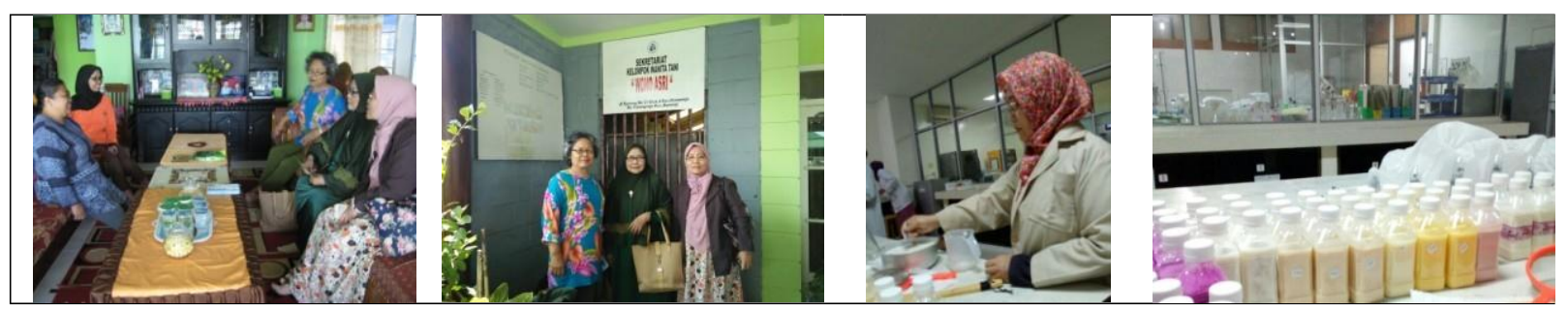

Gambar 1. Dari kiri ke kanan: koordinasi dengan Ketua PKK RW dan Ketua

Kelompok Wanita Tani "Wonoasri”, meninjau lokasi Kelompok, formulasi dan preparasi susu probiotik di Laboratorium Analisis Mikrobiologi Fakultas Farmasi Unair.

Tahap pelatihan berlangsung satu hari, dilanjutkan dengan pendampingan untuk karakterisasi produk dan pengemasan pada keesokan harinya karena fermentasi susu sapi perah menghasilkan susu probiotik membutuhkan waktu minimal 8 jam. Pelatihan berlangsung di Balai Pertemuan Dusun Wonorejo, peserta pelatihan dibagi dalam kelompok kecil sehingga tiap peserta mendapat kesempatan untuk praktek. Kegiatan yang meliputi: persiapan acara pelatihan di lokasi, pembukaan acara oleh Ketua PKK Dusun Wonorejo, penyuluhan oleh narasumber yang dibantu peragaan oleh mahasiswa, praktek pembuatan oleh peserta, dan kemudian dilanjutkan dengan pendampingan karakterisasi produk dirangkum pada Gambar 2. 


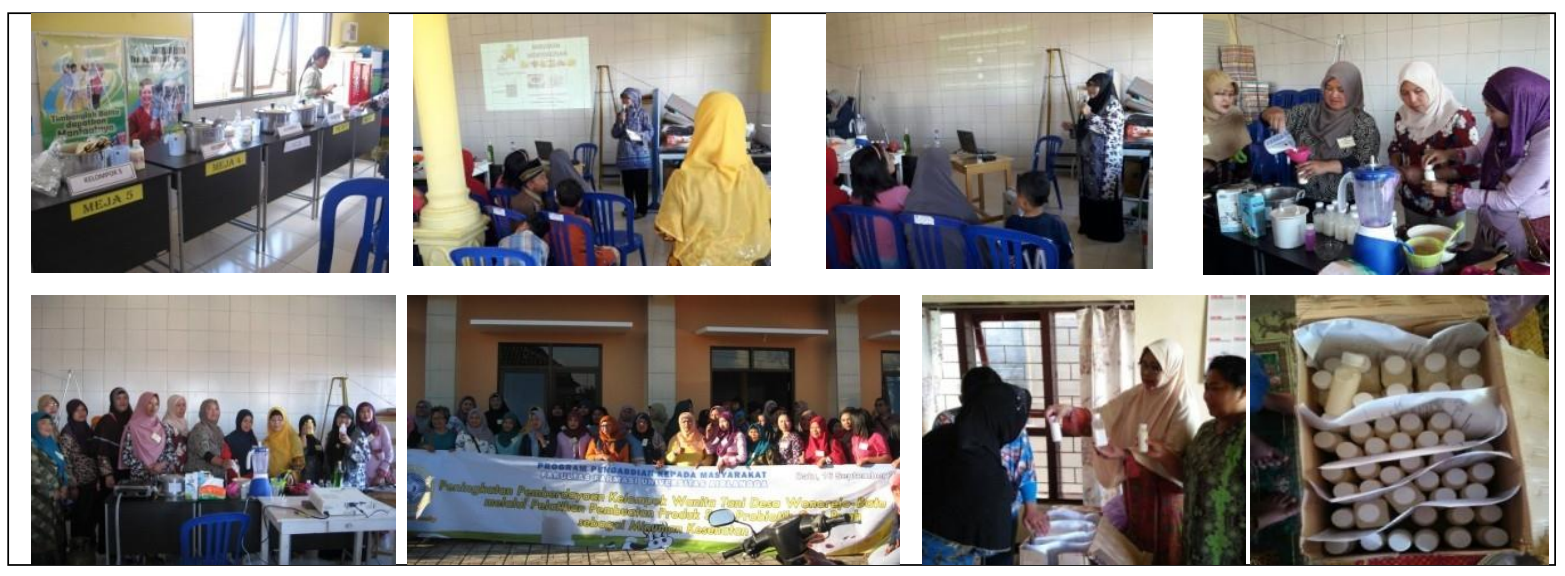

Gambar 2. Rangkaian acara pelatihan pembuatan susu probiotik-sari buah di Balai Pertemuan Dusun Wonorejo, yang keesokan harinya dilanjutkan dengan pendampingan untuk menganalisis produk yang dihasilkan peserta di lokasi Kelompok Wanita Tani.

Dari analisis karakter produk yang terbentuk, yaitu: warna putih tulang, konsistensi kental tidak mudah dituang, bau khas, rasa asam, disimpulkan bahwa semua peserta pelatihan berhasil membuat susu probiotik. Keberhasilan program juga dievaluasi berdasarkan jawaban post test. Ada 10 pertanyaan dalam bentuk pilihan ganda yang dievaluasi, dan hasilnya ditampilkan pada Gambar 3. Pilihan jawaban post test yang diharapkan untuk pertanyaan nomor $1,2,4,6$, dan 8 adalah $\mathrm{B}$, untuk pertanyaan nomor 3, 5, 10 adalah $\mathrm{C}$, dan untuk pertanyaan nomor 7 dan 9 adalah $\mathrm{A}$.

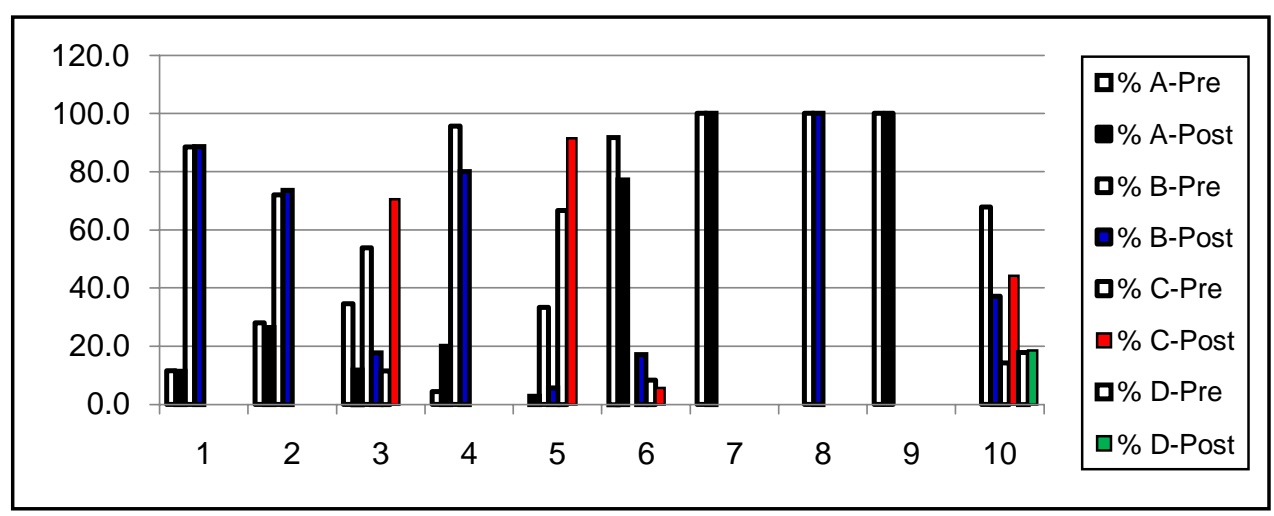

Gambar 3. Histogram distribusi persentase jawaban pre test dan post test peserta

Berdasarkan data persentase jawaban tersebut (Gambar 3), kegiatan ini berhasil meningkatkan pengetahuan tentang fungsi susu probiotik dan tujuan mengkonsumsi susu probiotik adalah untuk kesehatan, meningkatkan minat untuk membuat produk susu probiotik secara mandiri, dan meningkatkan jumlah khalayak yang ingin memproduksi susu probiotik dengan tujuan untuk keperluan keluarga dan dijual untuk meningkatkan pendapatan.

Dari pelaksanan dan evaluasi kegiatan, luaran program ini secara spesifik adalah: (1) produk minuman sehat susu probiotik-sari buah, yang dapat dinikmati oleh keluarga dan diharapkan akan dipasarkan secara berkelompok sebagai anggota UKM, (2) prosedur sederhana tentang pembuatan susu probiotik yang higienis, yang telah dibagikan dalam 
bentuk buku panduan sehingga dapat disebarkan oleh peserta pelatihan kepada warga masyarakat yang lebih luas. Secara umum, luaran kegiatan pengabdian masyarakat ini antara lain: (1) peningkatan pemberdayaan kelompok masyarakat dan kapasitas lembaga masyarakat terkait; (2) peningkatan keterlibatan dan jangkauan perguruan tinggi dalam kegiatan masyarakat; (3) peningkatan penyerapan manfaat hasil kegiatan penelitian dan pengabdian kepada masyarakat; dan (4) diseminasi hasil kegiatan dalam bentuk publikasi.

\section{PENUTUP}

\section{Simpulan dan Saran}

Kegiatan pengabdian pada masyarakat tentang pelatihan pembuatan susu probiotik-sari buah mendapatkan respons yang baik dari khalayak sasaran dan telah berhasil meningkatkan pengetahuan dan ketrampilan Kelompok Wanita Tani "Wonoasri” yang merupakan upaya peningkatan pemberdayaan kelompok masyarakat di Dusun Wonorejo. Kegiatan ini juga berhasil memberikan luaran spesifik, yaitu buku panduan tentang prosedur pembuatan produk, dan produk susu probiotik-sari buah sebagai minuman kesehatan.

Masih banyak warga masyarakat penghasil susu sapi perah namun mereka belum mampu memanfaatkannya secara maksimal, sehingga jangkauan masyarakat sasaran untuk pelatihan dan pembimbingan seperti ini dapat diperluas dengan menyesuaikan bahan baku sesuai kondisi dan potensi daerah masing-masing. Peningkatan kemampuan untuk menghasilkan produk susu probiotik yang bermanfaat bagi kesehatan dan bernilai jual tinggi akan meningkatkan kemampuan wirausaha masyarakat.

\section{UCAPAN TERIMA KASIH}

Kami menyampaikan terimakasih kepada Pimpinan Fakultas Farmasi dan LP4M Universitas Airlangga yang telah membantu pendanaan dan memfasilitasi pelaksanaan program Pengabdian pada Masyarakat ini.

\section{DAFTAR PUSTAKA}

Akaibara. 2016. Profil Kecamatan Bumiaji, Kota Batu, dalam ngalam.com/2016/09/11/pro Dinas Peternakan Jawa Timur. 2012. Teknologi Pengolahan Susu dalam rangka Kampanye

Isnaeni, Poernomo A.T, Nataly F. "Profil Bioautogram Bakteriosin dalam Susu Probiotik." Berkala Ilmiah Kimia Farmasi, Vol. 4, No.1 : 21-28.

Makanan Bergizi, disnak.jatimprov.go.id/web/

Muiz, AA. 2015. Industri Peternakan Rakyat Kota Batu Target Kelola 1.000 Ekor sapi, dalam suryamalang.tribunnews.com.

UPT Pembibitan Ternak dan Hijauan Makanan Ternak (UPT PT-HMT) Batu. 2016. Informasi Kegiatan dan Produk, dalam disnak.jatimprov.go.id/web/uptlab/ 